\title{
Synthesis Activated Charcoal of Malapari (Pongamia pinnata) Fruit peel
}

\author{
Ibrahim $^{1 *}$ \\ ${ }^{1}$ Department of Science Pharmacy, STIKES Sari Mulia Banjarmasin Indonesia \\ *e-mail: ibrahim@stikessarmulia.ac.id
}

Eti Rohaeti ${ }^{2}$

${ }^{2}$ Departmen of Chemistry, Bogor Agriculture University

er_a444@hotmail.com

Djeni Hendra ${ }^{3}$

${ }^{3}$ Center for Forest Products Research and Development Indonesia

djeni@gmail.com

\begin{abstract}
Objective: Utilizing malapari peel as a raw material of activated charcoal and determine its best quality.

Method: The samples were carbonized at a temperature of $300^{\circ} \mathrm{C}, 400^{\circ} \mathrm{C}$, and $450^{\circ} \mathrm{C}$. The resulting charcoal was activated chemically and physically. Activated charcoal was characterized based on SNI 06-37301995. The best quality activated charcoal was determined by its specific surface area. The best quality malapari peel was washed with $10 \% \mathrm{HCl}$. Furthermore, the best quality activated charcoal before and after being washed with $10 \% \mathrm{HCl}$ was analyzed micrograph using Scanning Electron Microscopy-Energy Dispersive Analysis X-Ray (SEM-EDAX).

Results: Carbonization of samples at $450^{\circ} \mathrm{C}$, continued activation by $2 \%$ phosphoric acid, and physical activation at $750^{\circ} \mathrm{C}$ by vapor streaming for 60 minutes produced the best quality activated charcoal by a methylene blue adsorption capacity of $119.50 \mathrm{mg} / \mathrm{g}$. The active charcoal was washed by $10 \% \mathrm{HCl}$ was able to increase the adsorption capacity of the methylene blue solution to $193 \mathrm{mg} / \mathrm{g}$ fulfilling the requirements of SNI 06-3730-1995 by specific surface area and pore surface of $715 \mathrm{~m}^{2} / \mathrm{g}$ and 545.04 $\mu \mathrm{m}^{2}$.

Conclusion: The best quality activated charcoal was produced by $450^{\circ} \mathrm{C}$ temperature carbonization process, activated using $2 \%$ phosphoric acid followed by physics activation at $750^{\circ} \mathrm{C}$ by vapor flow for 60 minutes.
\end{abstract}

Keywords: activated charcoal, activation, carbonization, malapari peel

\section{INTRODUCTION}

Currently, the utilization of malapari as a biofuel was found in India [2]. But the process left an untapped peel. Meanwhile, the prospect of bio-fuel processing based on raw fruit very promising because of its easy breeding. One hectare malapari population can produce 9 tons of dried malapari seeds, although the plant age is more than 50 years old but still produce seeds [16]. So it needs to be studied early on the utilization of the malapari peel in order to increase added value and not pollute the environment.

Malapari fruit peel texture is quite hard, likely contains lignin and selolusa that can be used as a source of carbon in the manufacture of activated charcoal. Several researchers have 
also reported waste utilization as a carbon source in the production of activated charcoal such as solid waste agar [4], tapioca solid waste [13], coconut and straw fibers [18] and wood puspa logging waste [10].

The process of making activated charcoal can be through two stages, namely carbonization, and activation. The process of carbonization is by using pyrolysis method, namely the thermochemical decomposition process with high temperature to the organic material without air. There are two activation processes, namely physical activation, and chemical activation. The principle of physical activation is the provision of water vapor or $\mathrm{CO}_{2}$ to the heated charcoal, whereas the chemical activation is the immersion of the charcoal in chemical solutions such as $\mathrm{CaCl}_{2}, \mathrm{ZnCl}_{2}$, $\mathrm{H}_{3} \mathrm{PO}_{4}, \mathrm{NaOH}, \mathrm{KOH}$, and $\mathrm{Na}_{2} \mathrm{SO}_{4}$ [20].

In this research, malapari fruit peel becomes activated charcoal by carbonization at $300^{\circ} \mathrm{C}$, $400^{\circ} \mathrm{C}$ and $450^{\circ} \mathrm{C}$ temperature. Meanwhile, the activation process was carried out by immersion in $1 \%$ and $2 \% \mathrm{H}_{3} \mathrm{PO}_{4}$ solution, so that the activated charcoal was produced chemically, then the activated charcoal was heated at the activation furnace with a temperature of $750^{\circ} \mathrm{C}$ while steam for 60 and 90 minutes, to obtain activated charcoal Chemically-physically. $\mathrm{H}_{3} \mathrm{PO}_{4}$ not only functions as an activator but also as a protective material from heat [19]. So the presence of $\mathrm{H}_{3} \mathrm{PO}_{4}$ can also be interpreted as a substance that slows down the rate of carbon oxidation reaction so that the yield of activated charcoal is increased.

\section{METHOD}

\section{Time and Location of Research}

This research was conducted from February to June 2014 at Laboratory Center for Forest Products Research and Development Indonesia.

\section{Sample}

The Sample was used in the research was malapari fruit peel from Batu Karas, West Java.

\section{Carbonization}

Calipari fruit peel was weighed and then carbonized with three treatments at $300^{\circ} \mathrm{C}$, $400^{\circ} \mathrm{C}$, and $450{ }^{\circ} \mathrm{C}$ pyrolyzes. Pyrolysis was performed in a stainless steel furnace for 4 hours. Then the carbonization was turned off and allowed to cool ( \pm 20 hours). The charcoal was removed and the rendement was determined, followed by the activation process.

\section{Activation}

The charcoal of malapari fruit peel was chemically activated by soaking in $1 \%$ and $2 \%$ phosphoric acid solution for 24 hours. Then it was drained, washed and dried by solar heat, to obtain chemically activated charcoal [22]. Thereafter, chemically activated charcoal went into the physical activation furnace reactor. The furnace reactor was prepared by increasing the temperature to $750{ }^{\circ} \mathrm{C}$ gradually until reaching the constant temperature and the pressure was made constant at 35 mbar. Water vapor is also carried in the reactor with time 60 and 90 minutes [14]. After the activation process was completed, the furnace reactor was allowed to cool ( \pm 24 hours) and in this process would be produced charcoal activated chemicallyphysically. The activated charcoal of malapari fruit peel yielded was weighed and determined its rendement and smoothed with a size of 200 mesh using Milling Herzog for 1 minute. This process produces 12 treatments such as Table 1 . 
Table 1 The condition of activated charcoal making of malapari fruit peel

\begin{tabular}{|c|c|c|c|c|c|c|c|}
\hline \multirow{2}{*}{ Treatment } & \multicolumn{3}{|c|}{ Carbonization $(\mathrm{K})$} & \multicolumn{2}{|c|}{ Activation Chemically (H) } & \multicolumn{2}{|c|}{ Activation Physically $\left(750^{\circ} \mathrm{C}\right)(\mathrm{S})$} \\
\hline & $300^{\circ} \mathrm{C}(3)$ & $400^{\circ} \mathrm{C}(4)$ & $450(45) \mathrm{C}$ & $\mathrm{H}_{3} \mathrm{PO}_{4} 1 \%(1)$ & $\mathrm{H}_{3} \mathrm{PO}_{4} 2 \%(2)$ & Steam 60 second (6) & Steam 90 second (9) \\
\hline K3H1S6 & $\sqrt{ }$ & & & $\sqrt{ }$ & & $\sqrt{ }$ & \\
\hline K3H1S9 & $\sqrt{ }$ & & & $\sqrt{ }$ & & & $\sqrt{ }$ \\
\hline K3H2S6 & $\sqrt{ }$ & & & & $\sqrt{ }$ & $\sqrt{ }$ & \\
\hline $\mathrm{K} 3 \mathrm{H} 2 \mathrm{~S} 6$ & $\sqrt{ }$ & & & & $\sqrt{ }$ & & $\sqrt{ }$ \\
\hline K4H1S6 & & $\sqrt{ }$ & & $\sqrt{ }$ & & $\sqrt{ }$ & \\
\hline K4H1S9 & & $\sqrt{ }$ & & $\sqrt{ }$ & & & $\sqrt{ }$ \\
\hline K4H2S6 & & $\sqrt{ }$ & & & $\sqrt{ }$ & $\sqrt{ }$ & \\
\hline K4H2S9 & & $\sqrt{ }$ & & & $\sqrt{ }$ & & $\sqrt{ }$ \\
\hline K45H1S6 & & & $\sqrt{ }$ & $\sqrt{ }$ & & $\sqrt{ }$ & \\
\hline K45H1S9 & & & $\sqrt{ }$ & $\sqrt{ }$ & & & $\sqrt{ }$ \\
\hline K45H2S6 & & & $\sqrt{ }$ & & $\sqrt{ }$ & $\sqrt{ }$ & \\
\hline K45H2S9 & & & $\sqrt{ }$ & & $\sqrt{ }$ & & $\sqrt{ }$ \\
\hline
\end{tabular}

Activated charcoal from malapari fruit peel obtained in characterization based on SNI 063730-1995. These characteristics include determination of moisture content, ash content, flying ash content, bound carbon content, an adsorption capacity of benzene, iodine and methylene blue. The specific surface area of activated charcoal of malapari fruit peel was determined by the adsorption capacity of methylene blue. The activated charcoal of malapari fruit peel with the highest specific surface area was the best quality activated charcoal. The activated charcoal was washed with $\mathrm{HCl} 10 \%$ to remove the impurities. Activated charcoal of best quality malapari peel before and after washing with $\mathrm{HCl} 10 \%$ analyzed micrograph by Scanning Electron Microscope-Energy Dispersive Analysis X-Ray (SEM-EDAX) to see different the pore area and the impurity surface area.

\section{RESULT}

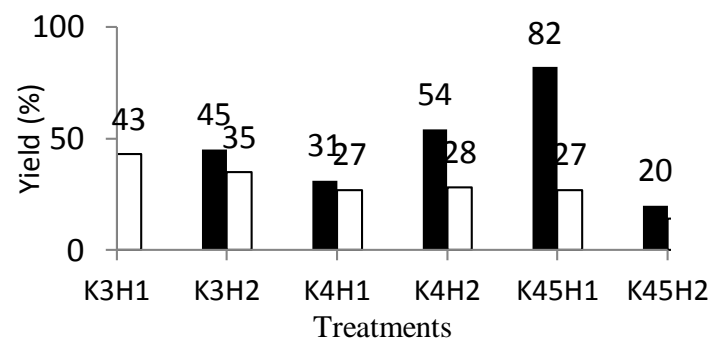

Figure 1 The influence of chemical-physical activation with the duration of water vapor 60 minutes $(\square$ and 90 minute ( $\square$ ) on the activated charcoal rendement.

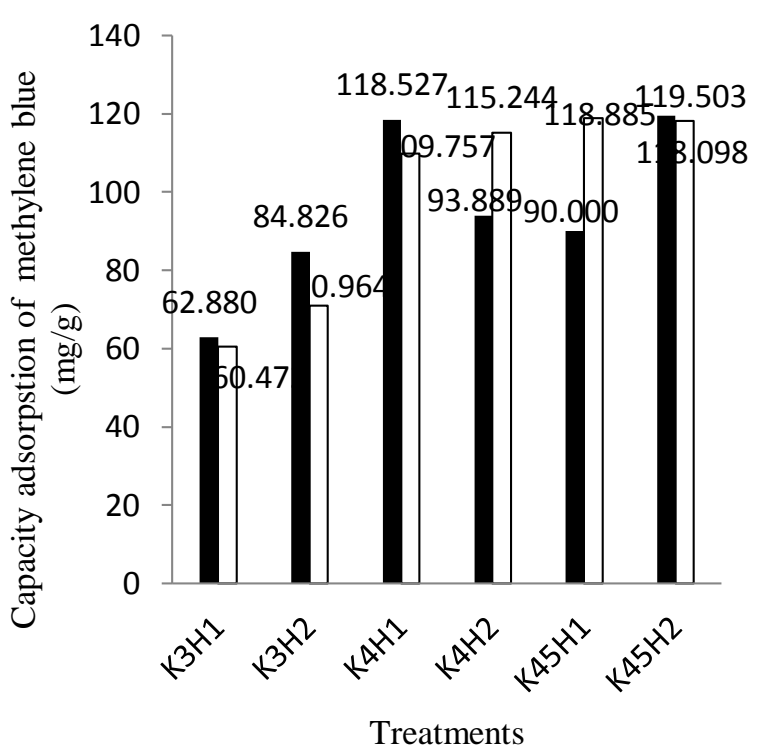

Figure 2 The effect of chemical-physical activation with water vapor flowing for 60 minutes $(\square)$ and 90 minutes ( $\square$ ) on methylene blue adsorption capacity.

\section{DISCUSSION}

The activated charcoal of malapari peel generated from different carbonization temperatures and means of activation will produce different characteristics. It was due to the rate of decomposition of different feedstocks with an increase in carbonization temperature. The more components that break down the more potential pore formation. At $300^{\circ} \mathrm{C}$ there has been decomposition of selolusa and at temperatures above $300^{\circ} \mathrm{C}$ not only 
decomposed of selolusa, but also decomposed of lignin. The decomposed component forms charcoal, $\mathrm{CO}, \mathrm{CO}_{2}, \mathrm{CH}_{4}$, phenol, ash, and tar [11]. It had evidenced by the decrease of charcoal yield along with the increase of carbonization temperature due to the formation of volatile components such as $\mathrm{CO}, \mathrm{CO}_{2}$, and $\mathrm{CH}_{4}$. During the carbonization process, the carbonaceous material undergoes a fragmentation process to form a thermostable aromatic structure that initiates polyaromatic formation. The process occurs at a carbonization temperature of $\pm 400^{\circ} \mathrm{C}$ [15].

The size of the formed charcoal pore was still small because it was covered by ash, tar, and resin formed during the carbonization process. Components formed from the decomposition of lignin during the carbonization process were shown in Figure. 3. The ash, tar, and resin components covering the pores can be removed through the activation process. The use of $\mathrm{H}_{3} \mathrm{PO}_{4}$ as activator material can expand activated charcoal pore by dissolving the ash and tar covering its pore [10]. $\mathrm{H}_{3} \mathrm{PO}_{4}$ also plays an important role in the formation of mesoporous and microporous structures in the inner structure of activated charcoal [21]. Thus, an increase in $\mathrm{H} 3 \mathrm{PO} 4$ concentration may provide an increased potential for the expansion and formation of activated charcoal pores. Further physical activation also plays an important role in the formation of pores through the process of decomposition of hydrocarbons to form volatile compounds because of the heat provided. The surface area of activated charcoal will increase with the loss of such volatile compounds [9]. This physical activation is accompanied by the flow of water vapor into the furnace reactor causing the reaction of carbon oxidation to form $\mathrm{CO}_{2}$ and $\mathrm{H}_{2}$ gases. The oxidation reaction increases with the increase of water vapor flow, so that the activated charcoal yield decreases (Figure 1). The yield of activated charcoal decreases with the increase of water vapor streaming time [13].

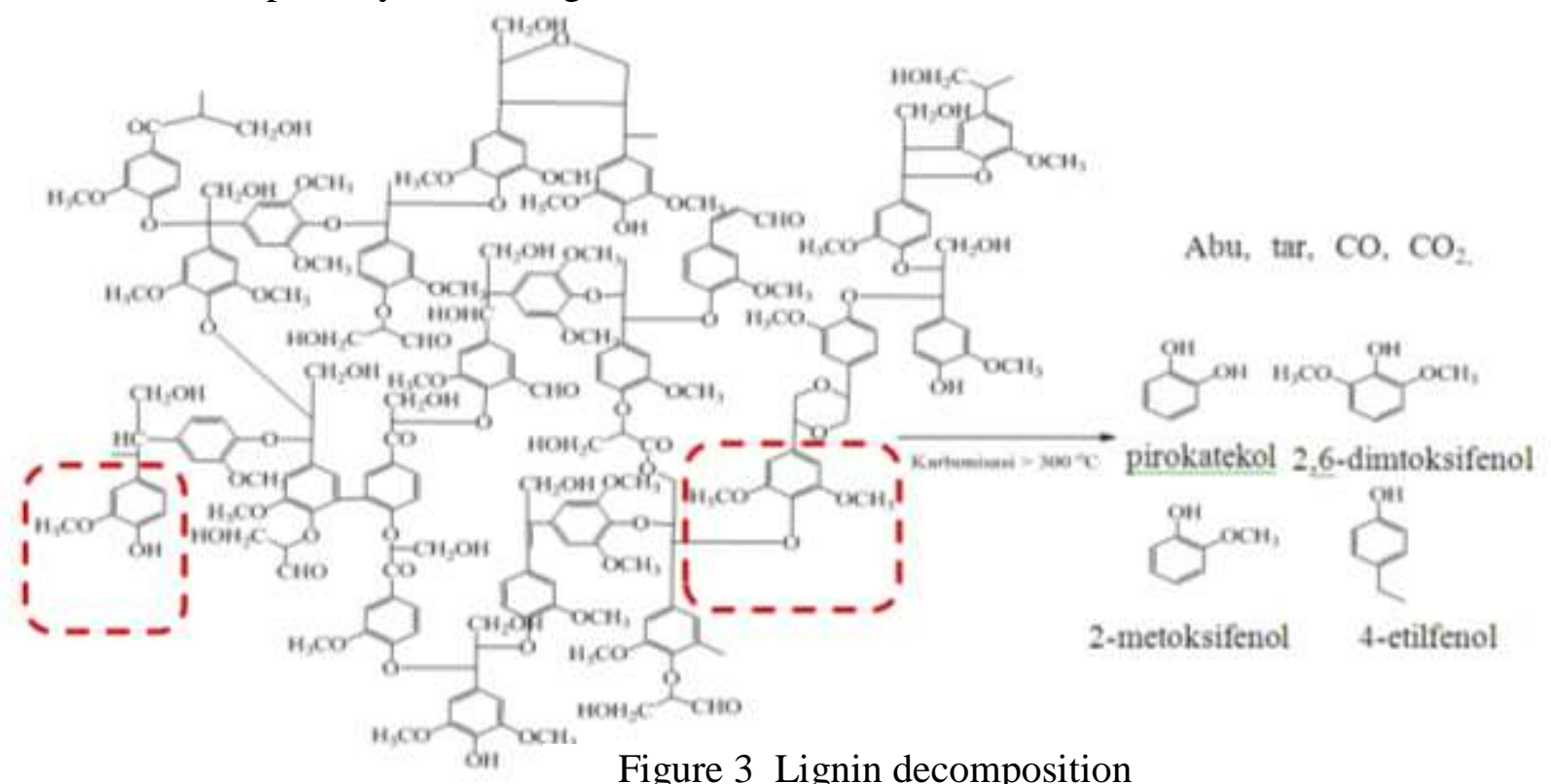

Figure 3 Lignin decomposition

The yield of activated charcoal also decreases with increasing $\mathrm{H} 3 \mathrm{PO} 4$ concentration due to the increasing of metal oxide, tar and resin together (Figure 1). The results characteristics of activated charcoal of malapari fruit peel indicate that only water content and flying substances meets the requirements of SNI 063730-1995. Low levels of carbon bound, iodine adsorption capacity, benzene, and methylene blue are influenced by high ash content. High ash content can cover the pores of activated charcoal of malapari peel, so its function as an adsorbent to the solution and gas decreases.

The best quality activated charcoal of malapari peel derived from carbonized raw materials at $450{ }^{\circ} \mathrm{C}$, chemically activated using $\mathrm{H} 3 \mathrm{PO} 42 \%$ 
followed by physical activation at $750{ }^{\circ} \mathrm{C}$ with vapor flow for $60 \mathrm{~min}$. The adsorption capacity of methylene blue solution of $119.50 \mathrm{mg} / \mathrm{g}$ (Figur. 2) with LPS of $443.08 \mathrm{~m}^{2} / \mathrm{g}$. It's adsorption capacity to methylene blue is greater than the activated charcoal from coconut shell activated with $\mathrm{ZnCl}_{2}$ [3] and activated charcoal from kapok seeds activated with $85 \%$ phosphoric acid [23], but smaller than the activated charcoal from tea seed shells activated with $\mathrm{ZnCl} 2$ [8] and activated charcoal from the bark of Chinese trees [6]. The higher the adsorption capacity of the methylene blue solution, the greater the specific surface area. Large the specific surface area causes more adsorbate molecules that can interact with adsorbate molecules.

Activated charcoal of malapari peel's ability to adsorb methylene blue increases with increasing carbonization temperature and phosphoric acid concentration (Figure 2). Increasing carbonization temperature can improve the decomposition of raw material components such as selolusa and lignin. Decomposition of the component causes the formation of pores, but is still covered by the impurities of ash and tar. The use of phosphoric acid as an activator serves to dissolve tar and minerals contained in the ash so that the pores open. Increasing the concentration of phosphoric acid may increase the dissolution of the impurities. Increased concentrations of phosphoric acid may increase pore volume [9]. The Activated charcoal of malapari peel adsorption capacity of the methylene blue solution decreased slightly with the increase of water vaporization time. It was probably caused by increased carbon oxidation, which could damage some of the pores that have been formed.

The best quality activated charcoal of malapari peel was washed with $\mathrm{HCl} 10 \%$ to remove the impurities. This washing aims to reduce the content of metal oxides and other impurities that potentially cover the pores of Activated charcoal of malapari peel. Analysis result using SEM-EDAX known surface Activated charcoal of malapari peel before washed with $10 \% \mathrm{HCl}$ looks dirty (Figure 4). The impurity components are oxides of sodium, magnesium, potassium, calcium, aluminum, silicon, sulfur, and chlorine (Figure 5). After washing, all impurities are lost except chlorine and potassium by $0.18 \%$ and $0.36 \%$ (Figure 6 ).

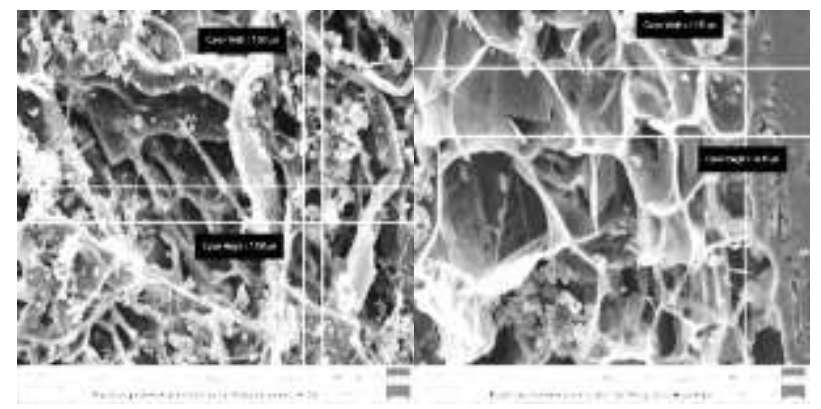

Figure 4 Micrograph activated charcoal of malapari peel and its composition before (left) and after (right) was washed with $\mathrm{HCl} 10 \%$

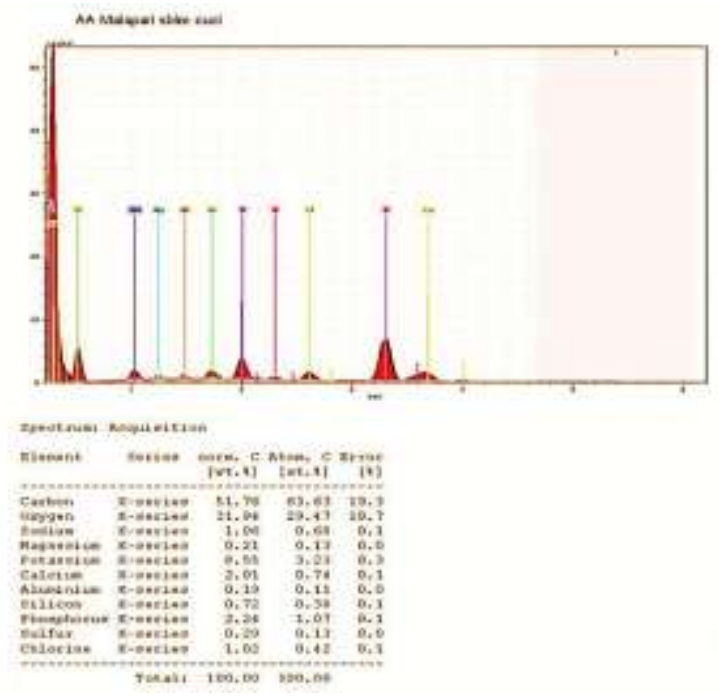

Figure 5 The content of metal on activated charcoal malapari before washed with $\mathrm{HCl} 10 \%$ 


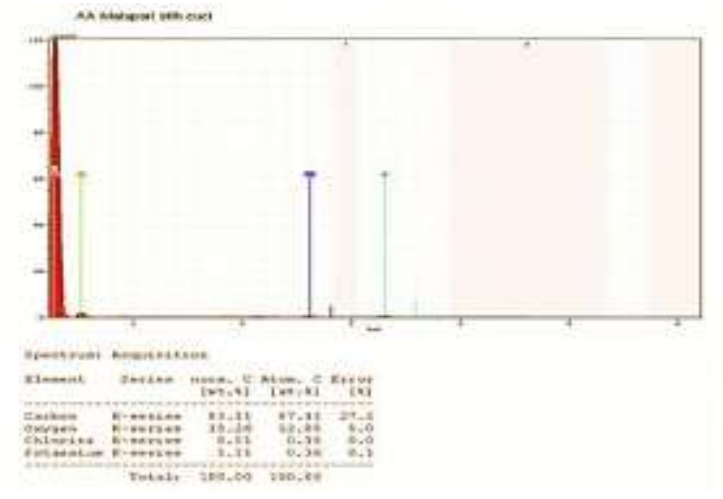

Figure 6 The content of metal on activated charcoal malapari after washing with $\mathrm{HCl} 10 \%$

The metal oxides formed during the carbonization process and the physics activation disappears from the charcoal activated surface as they change from the solid phase to the dissolved phase. The reaction involved was the salting reaction. This reaction produced salt and water. All of the salts formed from the oxide are soluble in water and could form an electrolyte solution [21]. Most of the chloride-containing compounds could be watersoluble at $25^{\circ} \mathrm{C}$, except those containing $\mathrm{Ag}^{+}$, $\mathrm{Hg}^{2+}$ and $\mathrm{Pb}^{2+}$. The metal oxide dissolution reaction was shown in the following reaction [7].

$$
\begin{aligned}
& \mathrm{Na}_{2} \mathrm{O}(\mathrm{s})+2 \mathrm{HCl}(a q) \rightarrow 2 \mathrm{NaCl}(a q)+\mathrm{H}_{2} \mathrm{O}(l) \\
& \mathrm{CaO}(\mathrm{s})+2 \mathrm{HCl}(a q) \rightarrow \mathrm{CaCl}_{2}(a q)+\mathrm{H}_{2} \mathrm{O}(l) \\
& \mathrm{MgO}(\mathrm{s})+2 \mathrm{HCl}(a q) \rightarrow \mathrm{MgCl}_{2}(a q)+\mathrm{H}_{2} \mathrm{O}(l) \\
& \mathrm{K}_{2} \mathrm{O}(\mathrm{s})+2 \mathrm{HCl}(a q) \rightarrow 2 \mathrm{KCl}(a q)+\mathrm{H}_{2} \mathrm{O}(l) \\
& \mathrm{Al}_{2} \mathrm{O}_{3}(\mathrm{~s})+6 \mathrm{HCl}(a q) \rightarrow 2 \mathrm{AlCl}_{3}(a q)+3 \mathrm{H}_{2} \mathrm{O}(l)
\end{aligned}
$$

The conversion of metal oxides to dissolved salts caused activated charcoal malapari peel surfaces to become cleaner (Figure. 5), resulting in increased pore area and specific surface area of $35 \mu \mathrm{m}^{2}$ and $443 \mathrm{~m}^{2} / \mathrm{g}$ to 138 $\mu \mathrm{m}^{2}$ and $715 \mathrm{~m}^{2} / \mathrm{g}$ respectively. The adsorption capacity of methylene blue also increased from $119.50 \mathrm{mg} / \mathrm{g}$ to $193 \mathrm{mg} / \mathrm{g}$ which has fulfilled the requirements of SNI 06-3730-1995 [5]. The resulting surface area is close to the commercial surface area of 200-325 mesh, ie $750 \mathrm{~m}^{2} / \mathrm{g}$ [1].
The surface area of activated charcoal malapari peel production is greater than the activated charcoal from kapok seed [23].

\section{CONCLUSION}

The activated charcoal of malapari fruit had been successfully created. Its characteristic was only water content and flying substance which fulfill the requirements of SNI 06-3730-1995. The best quality Activated charcoal of malapari peel was produced from a carbonized sample at $450^{\circ} \mathrm{C}$, activated with $2 \% \mathrm{H}_{3} \mathrm{PO}_{4}$ and continued activation at $750^{\circ} \mathrm{C}$ along by water vapor flow for $60 \mathrm{~min}$. The adsorption capacity of methylene blue is $119.50 \mathrm{mg} / \mathrm{g}$. Advanced washing by $10 \% \mathrm{HCl}$ increases the pore area of Activated charcoal of malapari peel and its adsorption capacity to methylene blue to 193 $\mathrm{mg} / \mathrm{g}$ (fulfilling the requirements of SNI 063730-1995). Specific surface area and Activated charcoal of malapari peel pores of $715 \mathrm{~m}^{2} / \mathrm{g}$ and $138 \mu \mathrm{m}^{2}$.

\section{REFERENCES}

[1] Aldrich Sigma. Activated Carbon Technical Information Bulletin. [Internet]. 2013. [diunduh 2014 Agustus 20]. Tersedia pada: www.sigmaaldrich.com/chemistry/chemica 1-synthesis/learning-

center/technicalbulletins/al-1430/activatedcarbon $/ \mathrm{html}$.

[2] Alimah D. Cultivation and potential malapari (Pongamia pinnata L.) pierre as a producing biofuel. Galam. 2010. 4(2):147-159.

[3] Anggarini D, Tjahjanto RT, Darjito. Studi aktivasi arang dari tempurung kelapa dengan pengozonan. Kimia Student Journal. 2(1). 400-407.

[4] Azalia N. Adsorben berbasis limbah padat agar-agar sebagai penjerap zat warna dan zat organik pada limbah industri batik. [Skripsi]. 2013. Bogor (ID). Institut Pertanian Bogor.

[5] [BSN] Standar Nasional Indonesia. SNI06-3730-1995: Arang aktif Teknis. Jakarta (ID). 1995: BSN. 
[6] Cao Y, Pawlowski A, Zhang J. Preparation of activated carbons with enhanced adsorption of cationic and dyes from Chinese hickory husk using the taguchi method. Environmental Protection Engineering. 2010. 36(3): 69-86.

[7] Chang R. Kimia Dasar: Konsep-Konsep Inti Edisi Ketiga. M. Abdulkadir Martoprawiro, Indra Noviandri, Deana Wahyuningrum, Buchari, Ismunandar, Hiskia Achmad, I Nyoman Marsih, dan Hidayat Muchsinuddi, penerjemah. Lemeda S, editor. Bandung (ID). 2003. Penerbit Erlangga. Terjemahan dari: General Chemistry: The Essential Concepts. Ed ke3.

[8] Gau J, Qin Y, Zhou T, Cao D, Xu P, Hochstetter D, Wang Y. Adsorption of methylene blue onto activated carbon produced from tea (Camellia sinensis L.) seed shells: kinetics, equilibrium, and thermodynamics studies. Journal of Zhejiang University-Science B. 2013. 14(7): 650-658.

[9] Gonzalez MAM, Susial P, Pena JP, Rodriguez JMD. Preparation of activated carbons from banana leaves by chemical activation with phosphoric acid. Adsorption of methylene blue. Revista Mexicana de Inngenieria Quimica. 2013. 12(3): 595-608.

[10] Hendra D. Pengolahan arang aktif dari limbah pembalakan kayu puspa dengan teknologi produksi skala semi pilot. Jurnal Penelitian Hasil Hutan. 2007: 119.

[11] Khah AM, Ansari R. Activated charcoal: preparation, characterization, and application: a review article. $J$ of Chemtech Research. 2009. 1(4):859-864.

[12] Kurniati, E., 2008, Pemanfaatan kulit sawit sebagai arang aktif. Jurnal Penelitian Ilmu Teknik. 8(2).

[13] Kurniawan T. Adsorben berbasis limbah padat tapioka. [Skripsi]. Bogor (ID). 2011. Institut Pertanian Bogor.

[14] Lempang M, Syafii W dan Pari G. Struktur dan komponen arang serta arang aktif tempurung kemiri. Jurnal
Penelitian Hasil Hutan. 2011. 3(29): 278284.

[15] Lempang M, Syafii W dan Pari G. Sifat dan mutu arang aktif tempurung kemiri. Jurnal Penelitian Hasil Hutan. 2012. 30(2): 100-113.

[16] Mardjono R. Mengenal ki pahang (Pongamia pinnata) sebagagai bahan bakar alternatif harapan masa depan. Warta Penelitian dan Pengembangan Tanaman Industri. 2008. 14(1):1-3.

[17] Mochida I, Yoon SH dan Qiao W. Catalysts in syntheses of carbon and carbon precursors. J. Bruz. Chem. Soc. 2006. 17(6): 1059-1073.

[18] Pakpahan JF, Tambunan T, Harimby A, Ritongga MS. Pengurangan FFA dan warna dengan adsorben serabut kelapa dan jerami. Jurnal Teknik Kimia. 2013. 2(1): 31-36.

[19] Sudradjat R dan Pari G. Tresnawati D, Setiawan D. Pengolahan arang aktif dari tempurung biji jarak pagar (Jatrophaa curcas L). Jurnal Penelitian Hasil Hutan. 2005: 1-25.

[20] Sudradjat R dan Pari G. Arang aktif:Teknologi Pengolahan dan Masa Depannya. Jakarta: Badan Penelitian dan Pengembangan Kehutanan. (ID). 2011.

[21] Vogel AI. Textbook of Macro and Semimicro Qualitative Inorganic Analysis Fith Edition. New York. 1979: Longman Inc. (US).

[22] Wibowo S, Syafii W dan Pari G. Karakteristik arang aktif tempurung biji nyamplung (Calophyllum inophyllum Linn). Jurnal Penelitian Hasil Hutan. 2010. 28 (1): 43-54.

[23] Widhianti WD. Pembuatan arang aktif dari biji kapuk (Ceiba pentandra L.) sebagai adsorben zat warna rhodamin B. [skripsi]. Surabaya (ID). 2010. Universitas Airlangga Surabaya.

[24] Yue, Economy Z, J dan Mangun CL. Preparation of fibrous porous materials by chemical activation $\mathrm{H}_{3} \mathrm{PO}_{4}$ activation of polymer coated fibers. Carbon. 2003. 41: 1809-1817. 